\title{
THEORETICAL AND APPLIED ASPECTS OF COMPREHENDING A NEW CONSTITUTIONAL DOCTRINE IN UKRAINE
}

\author{
Kateryna Holovko', Svitlana Levchenko², Oleg Dubinskiy ${ }^{3}$
}

\begin{abstract}
The article is devoted to the research of the nature and essence of some aspects of the new constitutional doctrine in Ukraine. Attention is paid to the basic constitutional and legal concepts actualized at the present stage of development of Ukraine as a democratic, legal, social state and building a civil society in it. Emphasis is placed on the issue of constitutional changes in Ukraine that have taken place over the last decades, both in the form of modernization and reform. The author concludes that qualitative and substantial upgrading of the theoretical and methodological base should be an integral part of constitutional and legal reform. The positions of the leading constitutionalist scientists on the essence of the category of "constitutional and legal doctrine" are analyzed, the significance of the dualism of approaches to its definition and peculiarities of influence on the rulemaking processes and enforcement are revealed. In addition, the importance of not only the process of forming a modern doctrine of constitutional law, the clear definition of basic concepts and general problems that operate and exploring the constitutional law of Ukraine as a science and as a leading branch of national law, but also the process of renewal the categorical apparatus, the introduction of the legal circulation of new categories capable of creating a more solid scientific basis for constitutional law, is proved. The subject of the research is the theoretical and applied aspects of comprehending the latest constitutional doctrine in Ukraine. The purpose is a study of the nature and essence of transformational changes in the constitutional and legal doctrine of Ukraine in view of the transformation processes in society at the present stage. The methodological basis of the research is a set of methods and techniques of scientific knowledge. The methodological construction is based on a systematic analysis that determined its directions. The systematic approach in some issues was supplemented by an axiological (ideological) approach. In order to identify trends, patterns and features of the development of constitutional law as a branch of law in the system of national law of Ukraine such empirical methods as observation, description, comparison and inductive generalization were used. Logical and semantic method was used for formulation and in-depth study of the conceptual apparatus. The dialectical cognition method allowed us to explore the problems associated with the definition of particular theoretical constructs, basic concepts and categories used in the Ukrainian constitutional and legal doctrine. The application of methods of modeling, analysis, synthesis, generalization and analogy made it possible to formulate the conclusions of the research. The conclusions of the research is that the author found that the content of the constitutional reform cannot be reduced to the problems of renewal of the Constitution as a normative legal act or its separate provisions, because its implementation goes beyond the procedural issues and tasks of the legal technique. At the same time, an essential component a qualitative and substantial renewal of the categorical and terminological apparatus of the branch of constitutional law should be part and parcel of the constitutional and legal reform of Ukraine. Special attention also needs to be paid to scientific and analytical monitoring of the state of the introduced changes and forecasting of the socio-political and legal consequences of the transformations, which will allow to expeditiously identify and correct possible mistakes, as well as to make recommendations on further perspectives of the development of the constitutional and legal branch. The practical implications. The results of the research will help to better understand the basic aspects of the latest constitutional doctrine in Ukraine and can be used in the research branch to further study the issue of transformational changes in the constitutional and legal branch.
\end{abstract}

Key words: doctrine, constitutional doctrine, constitutional reform, constitutional law of Ukraine, constitutionality, constitutionalization, constitutionalism, constitution.

JEL Classification: K15, K19, K38

\footnotetext{
Corresponding author:

${ }^{1}$ Black Sea Research Institute of Economy and Innovation, Ukraine.

E-mail: k.v.mozharovska@gmail.com

${ }^{2}$ Black Sea Research Institute of Economy and Innovation, Ukraine.

ORCID: https://orcid.org/0000-0002-3386-5962

E-mail: lightstarpro@ukr.net

${ }^{3}$ Admiral Makarov National University of Shipbuilding, Ukraine.

E-mail: dubinskiy_oleg@ukr.net
} 


\section{Introduction}

On the way towards development of civil society in Ukraine and the corresponding democratic, social, ruleof-law state, the problem of doctrinal justification and theoretical rethinking of some fundamental provisions by the constitutional law takes new features. The constitutional transformations in Ukraine, which have taken place over the last decades both in the form of modernization and reform with the main purpose to shape the system ofmodern Ukrainian constitutionalism, do not always objectively lead to an innovative transformation into new realities. This is explained by the fact that society and the expert community in Ukraine treat constitutionalism rather with restraint (because not everyone can dully understand the modern Ukrainian constitutionalism, although it has become more or less an idealistic doctrine), but the state still suffers from a systemic unsoundness of self-actions, a bureaucracy management, stable paternalism. At the same time, value of the constitutionalism as the most perfect form of implementation of the rule of law, the level of formation of its framework and paradigm require fundamental understanding of the specifics of a wide range of social relations, development of the foundation for qualitative changes and transformations, which are planned to be implemented in key areas of the national life, integrated efforts of the scientists society that will help to develop the advanced axioms and constitutional imperatives for Ukraine, to overcome obstacles and risks in the national legal ideology and to accelarate and to simplify the basic state-forming processes effectively.

It should also be emphasized that, given the fundamentality (with respect to other branches) of constitutional law, which is possible to call the core of the national legal system and its constituent component (Skrypniuk, 2009), the development and essence of the system of other branches of public and private law in Ukraine depend directly on the qualities of constitutional law as a leading branch of national law. Therefore, the urgency of the conceptual renewal of the modern paradigm of the doctrinal interpretation of the constitutional law and constitutional regulation essence, the role that they must play in modern state-forming conditions and in the process of ensuring the interaction of the state and civil society, always requires a deep understanding and forecasting of social and political consequences of the transformations performed.

At the same time, despite the fact that a multiple pleiad of the leading Ukrainian scientists was engaged in researching the nature and essence of transformational changes in the constitutional and legal doctrine of Ukraine in the conditions of reforming, among which there are: M.O. Baimuratov, Yu.G. Barabash, O.V. Batanov, D.M. Bielov, P.O. Dobrodumov, S.S. Kvach, S.V. Kivalov, A.M. Kolodii, L.T. Kryvenko, A.R. Krusian, L.I. Letnianchyn, O.V. Martseliak,
M.P. Orzikh, N.M. Parkhomenko, O.V. Petryshyn, V.F. Pohorilko, A.O. Selivanov, V.L. Fedorenko, O.F. Frytskyi, V.M. Shapoval, Yu.S. Shemshuchenko and others; at the present stage many issues related to certain aspects of the newest constitutional doctrine in Ukraine have a high level of scientific novelty. That is why the relevance of the question regarding the theoretical and applied aspects of comprehending the newest constitutional and legal doctrine in Ukraine, the theoretical and practical significance of the chosen topic are not in doubt.

The purpose of the article is a study of the nature and essence of transformational changes in the constitutional and legal doctrine of Ukraine in view of the transformation processes in society at the present stage.

Methodological basis of the research is a set of methods and techniques of scientific knowledge. The methodological construction is based on a systemic analysis that determined its directions. The systemic approach in some issues was supplemented by the axiological (ideological) approach. In order to identify trends, patterns and features of the development of constitutional law as a branch of law in the system of national law of Ukraine such empirical methods as observation, description, comparison and inductive generalization were used. Logical-semantic method was used for formulation andin-depth study of the conceptual apparatus. The dialectical cognition method allowed us to explore the problems associated with the definition of particular theoretical constructs, basic concepts and categories used in the Ukrainian constitutional and legal doctrine. The application of methods of modeling, analysis, synthesis, generalization and analogy made it possible to formulate the conclusions of the research.

\section{The concept of constitutional doctrine}

It is significant that the constitutional law in modern legal science is considered in several aspects: as a branch of law in the system of national law, as a science and an educational discipline. However, as a branch of the national legal system, the constitutional law is a leading (fundamental) branch, which is important both for the national legal system and for the legal system of Ukraine as a whole, which is preconditioned by the high mission of affirming and guaranteeing the statehood of the Ukrainian people, territorial integrity, human freedom and rights. This branch involves a set of legal norms that are sanctioned, defined and guaranteed by the state and which regulates the most important social relations connected with the organization of state power (relationship of power) and the basics of the relationship between the individual and the state (Fedorenko, 2009; Fedorenko, 2017; Krusian, 2010). At the same time, the constitutional law differs from other branches of law, first of all, by the specifics of the sphere of public relations, which are regulated under its norms: 
1) the democratic foundations of the constitutional order; 2) the democratic status of the person and the citizen; 3) the democratic principles of the exercise of power (Slinko, Dakhova, Letnianchyn, 2019). This allows to assert with confidence that the noted branch undoubtedly holds a special and unique place among the fundamental branches of the domestic law.

Given the fundamentality (with respect to other branches) of constitutional law, which is the core of the national legal system and its constituent component, it is necessary to consider the exceptional importance and value of the national constitutional law doctrine; through reflecting the practical orientation of fundamental scientific research, it can be the starting point of a constructive consolidation of the efforts of scientists, politicians, statesmen to strengthen the constitutional order, which will fully meet the interests of the individual and the state as a whole (Nelin, 2015). Thus, pointing to the objective nature and determination of the transformation of the constitutional and legal doctrine, its close connection with the permanently ongoing constitutional process (Shemshuchenko, 2012), the other reasons that influence the rethinking of the current national doctrine of the constitutional law should be remembered. That is why we support the position of experts who argue that the change in the constitutional doctrine of modern Ukraine should be considered in its own methodological aspect in at least two dimensions: a) as a change in the theoretical and methodological background of scientific understanding of the essence of the constitutional law and the subject of the constitutional and legal regulation of a process that should embody the most important values of the modern world constitutionalism; b) as a change of the constitutional organization and functioning of the Ukrainian state, which should find new forms of interaction with civil society and provide those fundamental constitutional principles that make the state democratic, legal and social (Shemshuchenko, Skrypniuk, Yushchyk, Antonov, Kostetska, Kuian, Murashyn, Surzhynskyi, 2014).

At the same time, scientists express different views on the interpretation of the concept of the "constitutional doctrine". For example, N.A. Bohdanova justifies the attitude that doctrine is the particular theoretical entity in the system of science of the constitutional law. At the same time, according to the author, the nature of the logical generalization of constitutional and legal knowledge, semantic content and form, the doctrine is equal to the principles, theories, and concepts. It seems that each of these theoretical constructs can take on the properties of the doctrine, but the doctrine must bear additional strain in the science of the constitutional law and be specifically related to practice. The purpose of the doctrine is the affirmation, the imposition of ideas that make up its content with a view to their application in practice. Therefore, the doctrine is always more categorical and, under certain circumstances, more conservative than principle or theory, and is more or less dogmatic in nature (2001). It seems that the proposed definition of the "constitutional doctrine" is not fully correspondent to the state-of-the-art development of jurisprudence and the methodology of constitutional science, and is too narrowed and does not clarify the content of the category of interest.

A slightly different approach to interpreting the concept of the "constitutional doctrine" is in the works of T.M. Priakhina, who argues that the constitutional doctrine is a specifically formalized system of fundamental views on the essence, social purpose, legal nature, matter, internal and external forms of the Basic Law; it is a set of theories and concepts that determine the strategic perspectives of the constitutional development of the state, the place and role of the Constitution in the state, social and legal systems that set the constitutional standards of the relationship between the individual, society and the state. At the same time, the external forms of its expression, consolidation, which directly influences the degree of binding of its provisions are important for the constitutional and legal doctrine. It is one thing when the doctrine as an idea or a set of ideas is not embodied in legal regulations, and it is different when it is clearly enshrined at the constitutional level and determines the orientation of the legal system of the state. Such an idea is of the normative, binding nature (2002).

A similar position is supported by A.O. Selivanov, who says that the doctrine is a thoroughly authoritative scientific research, which is treated by a legislator as a public value and is performed as the legislative form when defining. Therefore, the doctrine identifies the conceptual framework of the development of legislation, formulates scientifically sound ideas about state-legal phenomena and processes, which, if defined by the legal community and professional community, are the basis for the development of relevant drafts. The latter, if passed by a legislator, institutionalize the new legal institutions, giving them a legal form (2009).

Often enough the constitutional and legal doctrine is considered as a set of philosophical and legal ideas of conceptual level, embodied in the Constitution and other legislative acts that determine the tendency of development of the state and society, the national legal system. But this does not deny its interpretation as a set of ideas about the role of the constitutional law set out in the scientific works of constitutionalist scientists, which are essential for the development of the theory and practice of constitutionalism, constitutional reform of society. Therefore, according to the scientists, the doctrines in the constitutional law can be attributed not only to the views of the constitutionalist scientists and their scientific works, but also to the fundamental conceptual ideas embodied in the Constitution and other legislative acts (Todyka, 2000). 
In turn, the concept of the "constitutional doctrine" has two meanings. According to the first of these, the "doctrine" can be understood as a set of concepts and theories formulated by jurists. The second one concerns the official constitutional doctrine formulated by the body exercising constitutional control. In this case, the concept of "official" implies that this type of the constitutional doctrine provides the final and binding interpretation of the constitutional norms, while other interpretations, even made by the most authoritative scientists, contain only the ideas of law, not the law itself. It should be noted that the official constitutional doctrine does not arise in a vacuum, it combines the academic legal doctrine with the legal content of the Constitution. Therefore, the official constitutional doctrine can be defined as the result of a series of interpretations of constitutional provisions carried out by the competent authority and based on the academic legal doctrine (Zhalimas, 2017).

Moreover, there is good justification in the legal literature that the legal doctrines should be distinguished by the degree of their detalization in legislative provisions. Thus, the established doctrines formulated by well-known scientific schools (scientists), recognized and developed by the international and national judicial institutions (for example, the doctrine of the rule of law, of a democratic state), are capable to perform a regulatory function by virtue of the fact of their recognition by the state (through consolidation in the Constitution, legislative acts, sanctioning by judicial practice). However, the doctrines that are fundamentally new to a particular legal system of legal institutions, which contain both substantive and procedural components, require their detailed legislative regulation. Such doctrines can only exercise their regulatory influence on legal practice if the proper legal basis for their functioning is enshrined in current legislation. Only then such doctrines will be able to unfold their regulatory potential in the process of shaping the practice of applying the relevant legal requirements (Hultai, 2013).

In summary, we fully agree with the position of O. Nelin, who states that disregard for the constitutional doctrine has negative consequences for the national legal system. First of all, it is connected with «planned», and often, hasty adoption of a large amount of laws by the Verkhovna Rada of Ukraine; a lot of them cannot be realized in advance and in this sense they are critically evaluated by the lawyers, and most importantly by the Ukrainian people (2015). It appears that the inconsistencies and shortcomings of the Ukrainian legislation development are due to the fact that it is not the results of researches,views, scientific standpoints which justify the formation of the constitutional doctrine, but on the contrary, the "current" legislation compels the creation of so-called "doctrine of its application".

\section{Constitutional reform and modernization}

It is necessary to fully agree with the estimations of those scientists who uphold the position that the retrospective constitutional transformations in Ukraine were in the form of modernization and reform, but not always receiving doctrinal justifications with the necessary analysis and prognosis of the socio-political and legal consequences of these transformations, which were related to the reform "going above" its own subject of the constitutional law into the sphere of the systemic and structural qualitative changes in the state-legal and public life (Orzikh, 2010). Therefore, it seems that it is now necessary to give a more detailed assessment to the processes of modernization and reformation of the constitutional framework of the state and society, provided the indisputable constitutionalization of public and state life.

Considering the conceptual positions of the new doctrine of the Ukrainian constitutional law, it should be noted that it is necessary to understand the difference between constitutional modernization and reform. Thus, the broader range of law-regulation is more often considered in the latter as stepping of managing changes, systematicity of the constitutional, the political and legal transformations carried out in the process of the constitutional reform, the dynamics of constitutional relations, the full or partial transformation of the Constitution and constitutional legislation, the formation of constitutional legal consciousness to perceive constitutional transformations as an objectively useful necessity, to create a functional mechanism ensuring and protecting the constitutional order and constitutional legitimacy, the integration of constitutional legislation and constitutional realities into the system of modern constitutionalism (Lazarenko, 2016).

However, the modernization of constitutional existence and constitutional and legal realities does not always mean the introduction of textual amendments to the Constitution of Ukraine or the transformation of its certain provisions. Constitutional modernization is possible both in the form of changes in constitutional normative verbal foundations and in the form of interpretation of constitutional norms, which leads to increased attention to the activities of the Constitutional Court of Ukraine: the only body authorized for official interpretation of the Constitution of Ukraine, determination of the constitutionality of acts of state authorities (Orzikh, 2010).

Therefore, in view of renewal of the main aspects and key characteristics of the branch of constitutional law, it is definite that the institutional reform differs qualitatively from modernization in terms of means and consequences. However, the classic form of the constitutional reform implies realization of the politicallegal and organizational measures aimed at adopting a new constitution or its qualitative change of the 
current version according to certain legal procedures, aimed at developing constitutional relations and constitutional legal consciousness, creating a system of ensuring (protection) of the constitutional order with the aim of forming a modern constitutionalism (Lazarenko, 2016).

At the same time, the constitutional modernization must first and foremost be addressed to eliminate the existing defects and gaps in the constitutional law. This problem is important and urgent not only for Ukraine, but also for any other state, because in any constitution there are defects and gaps, which can be overcome as a prerequisite for the development of the modern constitutionalism (Krusian, 2008). It should be noted that the constitutional modernization implies not only the improvement of the text of the Basic Law, but also its "updating", that is, the introduction of features of the modern socio-political practice. After all, the Constitution must be improved and modified in accordance with changes that occur in connection with the development of a particular society and state, the evolutionary development of the system of national constitutionalism (Lazarenko, 2016).

It seems that this allows us to agree with the position of those who consider constitutional modernization not as a part of constitutional reform, but as its alternative, emphasizing that modernization will mean improving the existing constitutional model through the development of positive elements and minimizing the negative ones, while reform entails revising or even changing the current constitutional model (Balytnikov \& Ivanov, 2000). However, without a conceptual understanding of the further prospects for the development of the constitutional and legal sector, as well as the need and expediency of amending the constitutional legislation, there is no point to hope for the productive functioning of public authorities and civil society institutions. Unfortunately, the national legal system has repeatedly suffered from ill-considered reforms that distorted not only legislative activity and the quality of the legislative process, but also adversely affected the effective implementation of the rule of law.

\section{Transforming the paradigm of the Ukrainian constitutionalism}

The emerging concept of the Ukrainian constitutionalism implies that the constitutionalism is the centre and all the modern constitutional and legal issues "revolve around" it. Categorically it is a sufficiently universal carrier of theoretical energy of the modern constitutional law, the basic paradigm of constitutional practice, the criterion of the constitutionality of activities and acts of individual and collective subjects of law, the condition of formation of "dynamic constitutional jurisprudence", which, unlike "static", is oriented to form and use the laws and technical means of developing law, reforming constitutional reality. It should be noted that this approach is especially relevant for countries in transition, which is characterized to a large extent by the uncertainty of socio-political coordinates of society's development and requires an adequate constitutional and technological (engineering) solution, constitutional support for political reform (Orzikh, 2010).

In the context of developing the scientific and practical paradigm of the contemporary Ukrainian constitutionalism, it is impossible to overlook the achievements of A.R. Krusian, who views the modern constitutionalism as a public and legal system of the constitutional organization of modern society on the basis of law, democracy and the establishment of constitutional and legal human freedom, the content of which (of this system) is the constitution and constitutional legislation, constitutional relations, constitutional legal consciousness, its constitutional legal order and functioning aim at restricting (selflimiting) public authority for the benefit of civil society, human rights and freedoms (2010).

Given the fact that constitutionalism is a multilevel system that, which is although formally beyond the constitution, but is a reliable guarantee of its supremacy, as well as an important institutional and procedural guarantee of the constitutionalization of the legal order, it is now crucial to ensure the interaction between the theory and practice of constitutionalism. In particular, it is necessary to develop a common universal constitutional language of communication between constitutionalist scientists and practitioners. For this purpose, constitutional practice must be built on the basis and in accordance with the doctrinal concepts of the modern constitutionalism, and the theory should not be detached from real constitutionalism, but revived by its practical experience.

At the same time, it seems that the application of legal science and, in particular, the works of constitutionalist scientists, concerning the identification of key problems, the analysis of fundamental factors of influence, as well as the introduction of scientifically sound and systematic proposals, increases the efficiency of implementation of state-legal reforms, amending the Constitution, the solution to the problems of perfection of the state system and democracy, as well as the strengthening of law and order in the state.

\section{Conclusions}

It is obvious that from the standpoint of the development of the Ukrainian constitutional and legal doctrine, the branch of the constitutional law is undergoing transformation, which is caused by rethinking of values and priorities. However, even the formation of fundamentally new theoretical paradigms is unable to undermine the foundations of public recognition of the legitimacy of the state and its power, the rules of 
interaction that make it possible to guarantee the stability of the existence and development of Ukraine.

At the same time, it seems that the indisputable recognition of the value of constitutional law as a system of universal rules, values, principles and mechanisms that guarantee the stability, well-being and security of both citizens and the state should be the attributive characteristic of the new doctrine of the consstitutional law. At the same time, in the process of qualitative and substantial renewal, it is necessary to strictly adhere to the new ideology of development of the constitutional law, which should become a right not only of the state itself, but also of the law that ensures the interaction of a legal, democratic and social state with civil society. In this connection, the strategic priorities for the development of the Ukrainian state and society should remain crucial for the science of the constitutional law and constitutionalist scientists. However, all the mentioned above requires not only the dynamism of the constitutional and legal studies, but also the development of a unified strategy and algorithm of actions in order to avoid the illogical analysis of priority problems of national constitutional law science: the methodological and theoretical framework of its development, the system of the constitutional law of Ukraine, the development of constitutionalism and the theory of the constitution, the national sovereignty, improvement of the legal mechanism for ensuring human rights and freedoms and many other issues.

In this regard, in the conditions of development of Ukraine as a democratic and rule-of-law state, all reform initiatives should be systematic, be consistent with each other and take into account the new content of the constitutional doctrine, filled at the present stage with such values and principles that allowed it to become the basis for the development of the Ukrainian state, development and functioning of society, as well as the basis for an organic combination of the ideals of democracy, law, justice and prosperity. Only this approach will help to ensure the guaranteed progressive social development of Ukraine and to bring it to the highest level of social organization and functioning, which is native to the developed European societies, as well as to correct the shortcomings of the Ukrainian constitutionalism both at the theoretical (causes) and at the practical (effects) levels.

\section{References:}

Balyitnikov, V. V., \& Ivanov, V. V. (2000). K voprosu o konstitutsionnoy modernizatsii [Revisiting the constitutional modernization]. Konstitutsionnoe i munitsipalnoe pravo, 2, 167. (in Russian)

Bogdanova, N. A. (2001). Sistema nauki konstitutsionnogo prava: dis. ... d-ra yurid. nauk [The system of constitutional law science: thesis ... of Doctor of Juridical Sciences]. Moskva: Yurist. (in Russian)

Charles Howard Mcllwain. Constitutionalism Ancient and Modern, Ithaca, N.Y.: Cornell University Press, 1940, 3. Fedorenko, V.L. (2009). Systema konstytutsiinoho prava Ukrainy: teoretyko-metodolohichni aspekty: Monohrafiia [The system of the constitutional law of Ukraine: theoretical and methodological aspects: Monography]. Kyiv: Lira-K. (in Ukrainian)

Fedorenko, V. L. (2017). Systema konstytutsiinoho prava: poniattia, struktura, vzaiemozviazok z systemoiu konstytutsiinoho zakonodavstva [The system of the constitutional law: concept, structure, relationship with the constitutional law system]. Visnyk Luhanskoho derzhavnoho universytetu vnutrishnikh sprav im. E.O. Didorenka, 1, 27-36. (in Ukrainian)

Hultai, M. (2013). Do pytannia pro formuvannia doktryny konstytutsiinoi skarhy v Ukraini [To the question of formation of the doctrine of constitutional complaint in Ukraine]. Visnyk natsionalnoi akademii pravovykh nauk Ukrainy, 3, 117-127. (in Ukrainian)

Krusian, A. R. (2008). Preodolenie probelovi defektov vkonstitutsionnom prave Ukrainy kak uslovie formirovaniya sovremennogo ukrainskogo konstitutsionalizma [Crossing the gaps and defects in the constitutional law of Ukraine as a condition to form the modern Ukrainian constitutionalism]. Probely $i$ defekty $v$ konstitutsionnom prave i puti ikh ustraneniya: materialy mezhdunarodnoy nauch. konf. Moskva : Izdatelstvo Moskovskogo Universiteta. (in Russian) Krusian,A.R. (2010). Suchasnyiukrainskyikonstytutionalizm: monohrafiia [The modern Ukrainian constitutionalism: monography]. Kyiv: Yurinkom Inter. (in Ukrainian)

Krusian, A. R. (2010). Suchasnyi ukrainskyi konstytutionalizm: teoriia i praktyka: avtoref. dys. ... d-ra yuryd. nauk [The modern Ukrainian constitutionalism: theory and practice: abstract of the thesis of Doctor of Juridical Sciences]. Odessa. (in Ukrainian)

Lazarenko, S. V. (2016). Konstytutsiina reforma i modernizatsiia: spivvidnosheniia poniat [Constitutional reform and modernization: comparing concepts]. Molodyi vchenyi, 5, 424-427. (in Ukrainian)

Low Benjamin (2019). Full Powers and the Constitutional Doctrine of Implied Amendments. Singapore Journal of Legal Studies, September, pp. 390-422.

Michael Zuckert (2004). Natural Rights and Modern Constitutionalism. Northwestern Journal of International Human Right. Volume 2. Issue 1. URL: https://scholarlycommons.law.northwestern.edu/cgi/viewcontent. cgi? article $=1007 \&$ context $=$ njihr

Nelin, O. (2015). Konstytutsiina doktryna Ukrainy: problem kontseptualizatsii osnovnykh pidkhodiv [Constitutional doctrine of Ukraine: problems of basic approach conceptualization]. Yurydychna Ukraina, 9, 20-25. (in Ukrainian) 
Orzikh, M. P. (2010). Konstytutsiina modernizatsiia ta reformuvannia v Ukraini [Constitutional modernization and reform in Ukraine]. Naukovi pratsi Natsionalnoho universytetu «Odeska yurydychna akademiia», 9, $21-31$. (in Ukrainian)

Pryakhina, T. M. (2002). Konstitutsionnaya doktrina sovremennoy Rossii [The constitutional doctrine of modern Russia]. Saratov: Izdatelstvo Saratovskogo universiteta. (in Russian)

Selivanov, A. O. (2009). Sudove pravo : nova haluz prava chy teoretychna dumka? [Judicial Law: a new branch of law or theoretical thought]. Shchorichnyk ukrainskoho prava, 1, 77-84. (in Ukrainian)

Semenihin, I. (2018). Legal doctrine: aspects of understanding. Problemy zakonnosti, 141, 8-21.

Shemshuchenko, Yu. S. (2012). Problemy naukovoho zabezpechennia suchasnoho konstytutsiinoho protsesu v Ukraini [Problems of scientific support of the constitutional process of Ukraine]. Pravo Ukrainy, 8, 28-29. (in Ukrainian)

Shemshuchenko, Yu. S., Skrypniuk, O. V., Yushchuk, O. I., Antonov, V. O., Kostetska, T. A., Kuiian, I. A., Murashyn, H. O., \& Surzhynskyi, M. I. (2014). Problemy rozvytku konstytutsiinoho prava Ukrainy na suchasnomu etapi: teoriia i praktyka [Problems of development of the constitutional law of Ukraine at the present stage: theory and practice]. Pravova derzhava, 25, 66-97. (in Ukrainian)

Skrypniuk, O. V. (2009). Kurs suchasnoho konstytutsiinoho prava Ukrainy: akademichne vydannia [The course of modern constitutional law of Ukraine: academic publication]. Kharkiv: Pravo. (in Ukrainian)

Slinko, T. M., Dakhova, I. I., Letnianchyn, L. I. and other (2019). Konstytutsiine pravo Ukrainy: navch. posib. dlia pidhotovky fo zovnishnioho nezalezhnoho otsiniyvannia [Constitutional law of Ukraine: training manual for preparation to the external independent testing]. Kharkiv: Pravo. (in Ukrainian)

Todyka, Yu. M. (2000). Konstytutsiia i pravova doktryna [Constitution and legal doctrine]. Visnyk Akademii pravovykh nauk Ukrainy, 1, 42-50. (in Ukrainian)

Zhalimas, D. Ofitsiina konstytutsiina doktryna: konysepysiia, znachushchist, holovni pryntsypy rozvytku [Official constitutional doctrine: concept, relevance, main principles of development]. URL: https://krytyka.com/ua/ articles/ofitsiyna-konstytutsiyna-doktryna-kontseptsiya-znachushchist-holovni-pryntsypy-rozvytku 